\title{
Response of Boro Rice to Planting Stage of Seedlings and Nutrient Management under SRI
}

\author{
Dhiman Sen ${ }^{1 *}$, Swapan Kumar Maity ${ }^{1}$ and Prabir Mukhopadhyay ${ }^{2}$
}

${ }^{1}$ Dept. of ASEPAN, Institute of Agriculture, Visva-Bharati, Sriniketan, West Bengal (731 236), India

${ }^{2}$ Dept. of Soil Science and Agricultural Chemistry, UBKV, Pundibari, Cooch Behar, West Bengal (736 165), India

\section{Article History}

Manuscript No. AR1518

Received in $10^{\text {th }}$ January, 2016

Received in revised form $25^{\text {th }}$ March, 2016

Accepted in final form $6^{\text {th }}$ April, 2016

\section{Correspondence to}

*E-mail: sendhiman@rediffmail.com

\section{Keywords}

SRI, planting stage, FYM, Azospirillum, N management, LCC

\begin{abstract}
The current research work was carried out at the experimental field of Dakshin Dinajpur Krishi Vigyan Kendra, Majhian, South Dinajpur, West Bengal during Boro 2011-12 season. The experiment was laid out in factorial RBD design and replicated thrice. There were total twenty treatments out of which eighteen treatments were comprised of factorial combinations of two planting stages (planting at two leaved stage and three to four leaved stage), three sources of organic nutrients (FYM $10 \mathrm{t} \mathrm{ha}^{-1}$, FYM $5 \mathrm{t} \mathrm{ha}^{-1}$ and FYM $5 \mathrm{tha}^{-1}+$ Azospirillum biofertilizer) and three modes of $\mathrm{N}$ application (blanket split as $1 / 4$ basal $+1 / 2$ active tillering $+1 / 4$ panicle initiation, LCC based $\mathrm{N}$ application at critical value 3 and at critical value 4). The experiment included two absolute controls under each planting stage i.e. transplanting at two leaved stage and transplanting at three to four leaved stage. Two leaved stage transplanted treatment significantly increased plant height, number of tiller hill ${ }^{-1}$, dry matter production $\mathrm{m}^{-2}$, effective tillers hill ${ }^{-1}$, filled grains panicle ${ }^{-1}$, test weight, grain and straw yields in comparison to transplanting at three to four leaved stage. Among organic sources of nutrient, FYM $10 \mathrm{t} \mathrm{ha}^{-1}$ recorded significantly taller plant, more number of tiller hill-1, higher dry weight per square meter, effective tillers hill ${ }^{-1}$, filled grains panicle ${ }^{-1}$, test weight, grain and straw yields followed by FYM $5 \mathrm{t} \mathrm{ha}^{-1}+$ Azospirillum. On an average LCC treatments provided better response to obtain higher grain as well as straw yields and in between LCC based N applications, LCC at 4 showed better result than LCC at 3 .
\end{abstract}

\section{Introduction}

In India rice is the most important food crop having an average area of $43.4 \mathrm{mha}$ and $99.0 \mathrm{mt}$ of average production during 2008-09 to 2012-13 (G.O.I., 2014). It is estimated that in our country, the demand for rice will be $121.2 \mathrm{mt}$ by the year 2030, $129.6 \mathrm{mt}$ by the year 2040 and by the year 2050, the demand will be $137.3 \mathrm{mt}$ (CRRI, 2013). Conventional rice production consumes large quantities of irrigation water. SRI practices are reported to increase the yields of rice while reducing water requirements (Zhao et al., 2010). Optimally sparse population, transplanting seedlings at early age, intermittent flooding, active soil aeration and application of large quantities of organic matter are important management principles associated with SRI (Barison and Uphoff, 2011). It has been reported that the beneficial effects of different alternative SRI practices can be heightened, often dramatically, when they are combined with the transplanting of very young seedlings and increased applications of organic matter that improves soil structure and function (Mishra and Salokhe, 2008; Chapagain and Yamaji, 2010). So, planting stage and application of organic sources of nutrients are important issues in respect of SRI. Recent findings have shown that optimizing fertilizer $\mathrm{N}$ application rates under SRI is important to increase yield (Zhao et al., 2009). Singh et al. (2009a) emphasised that leaf colour chart (LCC) has emerged as visual and subjective indicator of plant $\mathrm{N}$ deficiency in rice. In India, agronomic researches in rice focus on resource conservation technologies among which LCC based $\mathrm{N}$ management (Mahapatra et al., 2012) is one of them to improve the nitrogen use efficiency in rice. Keeping all these in views, present study was aimed to evaluate different planting stages and nutrient management practices raised under System of Rice Intensification.

\section{Materials and Methods}

The current research work was carried out at the experimental field of Dakshin Dinajpur Krishi Vigyan Kendra (DDKVK), Majhian, South Dinajpur, West Bengal, India during Boro 2011-12 season. The crop was sown on 20.01.12 and harvested 
on 30.05.12. Soil of the experimental plot was silty clay in texture, medium in organic carbon $(0.63 \%)$, acidic in nature ( $\mathrm{pH}$ 5.49), medium in available nitrogen (347 $\left.\mathrm{kg} \mathrm{N} \mathrm{ha}^{-1}\right)$, medium in phosphorus $\left(25 \mathrm{~kg} \mathrm{P}_{2} \mathrm{O}_{5} \mathrm{ha}^{-1}\right)$ and low in potassium $\left(61 \mathrm{~kg} \mathrm{~K}_{2} \mathrm{O} \mathrm{ha}^{-1}\right)$ content. The experiment was laid out in factorial randomised complete block design and replicated thrice. There were total twenty treatments out of which eighteen treatments were comprised of factorial combinations of two planting stages (planting at two leaved stage and three to four leaved stage), three sources of organic nutrients (FYM $10 \mathrm{tha}^{-1}$, FYM $5 \mathrm{t} \mathrm{ha}^{-1}$ and FYM $5 \mathrm{t} \mathrm{ha}^{-1}+$ Azospirillum biofertilizer) and three modes of $\mathrm{N}$ application (blanket split as $1 / 4$ at basal $+1 / 2$ at active tillering $+1 / 4$ at panicle initiation, LCC based $\mathrm{N}$ application at critical value 3 and LCC based $\mathrm{N}$ application at critical value 4). The experiment included two absolute controls under each planting stage i.e. transplanting at two leaved stage and transplanting at three to four leaved stage. Rice variety IET 4094 (Khitish) was grown for the experiment. Seeds were sown on nursery bed on 20.01.2012 and transplanting for two leaved stage was done on 06.02.12 and for three to three to four leaved stage on 16.02.2012. Seedlings were transplanted to the main field at two leaved stage and three to four leaved stage at the spacing of $25 \times 25 \mathrm{~cm}^{2}$. In case of blanket split, $75 \%$ dose of recommended $\mathrm{N}$ i.e. $97.5 \mathrm{~kg} \mathrm{ha}^{-1}$ were applied in three splits $-1 / 4 \mathrm{~N}$ as basal (at the time of final land preparation), $1 / 2$ $\mathrm{N}$ at 15 days after transplanting and $1 / 4 \mathrm{~N}$ at panicle initiation stage. In case of LCC based $\mathrm{N}$ application, after 15 days of transplanting, LCC reading of randomly selected 10 healthy fully emerged young leaves were taken from each plot at 7 days interval. When average $\mathrm{LCC}$ value falls below the set value, top dressing of urea was done at the rate of $10 \mathrm{~kg} \mathrm{~N} \mathrm{ha}^{-1}$. All the plots were given $75 \%$ of recommended $\mathrm{P}$ and $\mathrm{K}$ doses i.e. at the rate of $48.75 \mathrm{~kg} \mathrm{P}_{2} \mathrm{O}_{5} \mathrm{ha}^{-1}$ and $48.75 \mathrm{~kg} \mathrm{~K}_{2} \mathrm{O} \mathrm{ha}^{-1}$. All P and $3 / 4$ part of $\mathrm{K}$ were applied at the time of final land preparation and rest $1 / 4$ part of $\mathrm{K}$ was top dressed at panicle initiation stage.

\section{Results and Discussion}

\subsection{Effect of planting stage, organic sources and mode of $N$ application on growth parameters}

Experimental findings presented in Table 1, expressed that planting stage, organic source and mode of $\mathrm{N}$ application significantly influenced growth parameters such as plant height, number of tiller per hill and dry matter production of boro rice. Between planting stages, two leaved stage transplanted treatment significantly increased plant height, number of tiller per hill and dry matter production per square meter over three to four leaved stage of transplanting. Among organic sources of nutrient, FYM $10 \mathrm{t} \mathrm{ha}^{-1}$ recorded significantly taller plant, more number of tiller hill-1 and higher dry weight per square meter followed by FYM $5 \mathrm{t} \mathrm{ha}^{-1}+$ Azospirillum and FYM $5 \mathrm{t}$ $\mathrm{ha}^{-1}+$ Azospirillum treatment was significantly responded in case of plant height and dry matter production over FYM $5 \mathrm{t}$ ha $^{-1}$ alone, but in case of tiller production hill-1 ${ }^{-1}$ FYM 5 t ha-

${ }^{1}+$ Azospirillum and FYM $5 \mathrm{t} \mathrm{ha}^{-1}$ were at par. Among mode of $\mathrm{N}$ applications, in respect of growth parameters like plant height, tiller numbers hill ${ }^{-1}$ and dry matter production per square meter, LCC treatments were significantly responded in a positive direction over blanket split $\mathrm{N}$ application, though in case of dry weight, LCC based N application at 3 was not significantly higher than blanket split treatment. Between LCC treatments, application of $\mathrm{N}$ at LCC 4 recorded numerically higher plant height as well as dry matter per square meter over LCC 3 and in case of tiller number hill-1 ${ }^{-1}$, LC 4 was significantly higher than LCC 3. Plant height, number of tiller hill ${ }^{-1}$ and dry matter production per square meter were registered significantly more in case of rest of the treatments over control treatments. Between control treatments, two leaved stage transplanted control treatment provided significantly more plant height as well as dry weight per square meter and numerically higher number of tiller hill-1 ${ }^{-1}$ over three to four leaved stage transplanted control treatment.

\subsection{Effect of planting stage, organic sources and mode of $N$} application on yield attributes

Yield attributes such as effective tillers hill ${ }^{-1}$, filled grains panicle $^{-1}$ and test weight, were significantly influenced by planting stages, organic sources and mode of $\mathrm{N}$ applications (Table 1). Panicle length was significantly influenced by organic sources of nutrient, but not influenced by planting stages and mode of $\mathrm{N}$ applications. Between planting stages, two leaved stage transplanting significantly increased effective tillers hill-1 ${ }^{-1}$, filled grains panicle ${ }^{-1}$ and test weight than three to four leaved stage transplanting. Among organic sources, FYM $10 \mathrm{t} \mathrm{ha}^{-1}$ recorded significantly higher effective tillers hill $^{-1}$, filled grains panicle ${ }^{-1}$ and test weight than FYM $5 \mathrm{t}$ ha $^{-1}+$ Azospirillum and it was significantly higher than FYM $5 \mathrm{t} \mathrm{ha}^{-1}$ treatment in respect of the parameters. Panicle length was observed maximum under FYM $10 \mathrm{t} \mathrm{ha}^{-1}$ which was numerically higher than FYM $5 \mathrm{t} \mathrm{ha}^{-1}+$ Azospirillum and significantly higher than FYM $5 \mathrm{t} \mathrm{ha}^{-1}$. Among mode of $\mathrm{N}$ applications, in respect of effective tiller hill-1 ${ }^{-1}$ and filled grains panicle ${ }^{-1}$, highest response obtained from the treatment with LCC based $\mathrm{N}$ application at 4 which was significantly higher than LCC 3 and it was significantly higher than blanket split treatment. Test weight recorded highest $(22.5 \mathrm{~g})$ under both the LCC treatments and they were significantly higher than blanket split. Effective tillers hill ${ }^{-1}$, panicle length, filled grains panicle ${ }^{-1}$ and test weight were recorded significantly higher under rest of the treatment over controls and between control treatments earlier transplanting provided better response in 


\begin{tabular}{|c|c|c|c|c|c|c|c|}
\hline Treatments & $\begin{array}{l}\text { Plant height } \\
\text { (cm) }\end{array}$ & $\begin{array}{l}\text { Number of } \\
\text { tiller hill }\end{array}$ & $\begin{array}{l}\text { Dry weight } \\
\left(\mathrm{g} \mathrm{m}^{-2}\right)\end{array}$ & $\begin{array}{l}\text { Effective } \\
\text { tiller hill }{ }^{-1}\end{array}$ & $\begin{array}{c}\text { Panicle } \\
\text { length }(\mathrm{cm})\end{array}$ & $\begin{array}{c}\text { Filled grains } \\
\text { panicle }^{-1}\end{array}$ & $\begin{array}{l}\text { Test weight } \\
\text { (g) }\end{array}$ \\
\hline \multicolumn{8}{|l|}{ Planting stage } \\
\hline$\overline{\mathrm{G}_{1}: 2 \text { leaved stage }}$ & 105.5 & 19.2 & 1279.0 & 17.5 & 26.9 & 164.9 & 22.6 \\
\hline $\mathrm{G}_{2}: 3-4$ leaved stage & 100.1 & 16.6 & 1136.0 & 14.0 & 26.3 & 154.7 & 22.3 \\
\hline $\operatorname{SEm} \pm$ & 0.6 & 0.3 & 20.4 & 0.2 & 0.3 & 1.5 & 0.01 \\
\hline $\operatorname{LSD}_{0.05}$ & 1.8 & 0.9 & 58.5 & 0.5 & NS & 4.2 & 0.04 \\
\hline \multicolumn{8}{|l|}{ Organic source } \\
\hline $\mathrm{M}_{1}: \mathrm{FYM}\left(10 \mathrm{t} \mathrm{ha}^{-1}\right)$ & 108.0 & 20.2 & 1342.0 & 18.2 & 27.2 & 174.5 & 22.7 \\
\hline $\mathrm{M}_{2}: \mathrm{FYM}\left(5 \mathrm{tha}^{-1}\right)$ & 97.8 & 16.3 & 1093.0 & 13.5 & 26.0 & 144.2 & 22.2 \\
\hline $\mathrm{M}_{3}: \operatorname{FYM}\left(5 \mathrm{tha}^{-1}+\mathrm{Azo}\right)$ & 102.6 & 17.3 & 1188.0 & 15.6 & 26.6 & 160.7 & 22.4 \\
\hline $\operatorname{SEm} \pm$ & 0.8 & 0.4 & 25.0 & 0.2 & 0.3 & 1.8 & 0.02 \\
\hline $\mathrm{LSD}_{0.05}$ & 2.2 & 1.1 & 71.6 & 0.6 & 0.9 & 5.2 & 0.05 \\
\hline \multicolumn{8}{|l|}{ Mode of $\mathrm{N}$ application } \\
\hline $\mathrm{N}_{1}$ : Blanket split & 98.9 & 16.4 & 1146.0 & 14.1 & 26.3 & 139.7 & 22.3 \\
\hline $\mathrm{N}_{2}: \operatorname{LCC} 3$ & 103.8 & 17.9 & 1206.9 & 15.9 & 26.6 & 155.8 & 22.5 \\
\hline $\mathrm{N}_{3}: \mathrm{LCC} 4$ & 105.7 & 19.4 & 1270.0 & 17.2 & 26.9 & 183.9 & 22.5 \\
\hline $\mathrm{SEm} \pm$ & 0.8 & 0.4 & 25.0 & 0.2 & 0.3 & 1.8 & 0.02 \\
\hline $\mathrm{LSD}_{0.05}$ & 2.2 & 1.1 & 71.6 & 0.6 & NS & 5.2 & 0.05 \\
\hline Control mean & 67.1 & 9.3 & 495.0 & 7.4 & 18.6 & 86.5 & 20.1 \\
\hline Mean of the rest & 102.8 & 17.9 & 1207.0 & 15.2 & 26.6 & 159.8 & 22.4 \\
\hline $\mathrm{SEd} \pm$ & 1.4 & 0.7 & 45.7 & 0.4 & 0.6 & 3.3 & 0.03 \\
\hline $\mathrm{LSD}_{0.05}$ & 2.9 & 1.4 & 92.5 & 0.8 & 1.3 & 6.7 & 0.06 \\
\hline $\mathrm{G}_{1}$ Control & 69.9 & 9.9 & 596.3 & 8.3 & 20.8 & 93.3 & 20.7 \\
\hline $\mathrm{G}_{2}$ Control & 64.4 & 8.7 & 393.7 & 6.5 & 16.5 & 79.7 & 19.4 \\
\hline $\mathrm{SEm} \pm$ & 1.9 & 0.9 & 61.3 & 0.5 & 0.8 & 4.4 & 0.04 \\
\hline $\mathrm{LSD}_{0.05}$ & 5.4 & NS & 175.5 & 1.5 & 2.4 & 12.7 & 0.11 \\
\hline $\mathrm{CV}(\%)$ & 3.3 & 9.5 & 9.3 & 6.1 & 5.6 & 5.1 & 0.3 \\
\hline
\end{tabular}

respect of the yield attributes.

\subsection{Effect of planting stage, organic source and mode of $N$ application on grain and straw yield}

Grain yield and straw yield were significantly influenced by all the factors i.e. planting stage, organic sources and mode of $\mathrm{N}$ application treatments (Table 2). Yields were recorded significantly higher with transplanting seedlings at two leaved stage. Both grain and straw yields were observed significantly higher when FYM $10 \mathrm{t} \mathrm{ha}^{-1}$ applied compared to FYM $5 \mathrm{t} \mathrm{ha}^{-1}+$ Azospirillum and FYM $5 \mathrm{t} \mathrm{ha}^{-1}+$ Azospirillum was significantly higher than FYM $5 \mathrm{t}^{-1} \mathrm{a}^{-1}$ treatment. Grain as well as straw yields under LCC based $\mathrm{N}$ application at 4 were numerically higher than the yields obtained from the LCC treatment at 3, but LCC at 4 was significantly higher than blanket split treatment. In respect of grain and straw yields, LCC 3 and blanket split treatments were at par. There was significant yield reduction in terms of grain and straw yields under control treatments than the mean of rest of the treatments and among control treatments, yields were reduced more when transplanted at three to four leaved stage than transplanting at two leaved stage.

\subsection{Effect of planting stage, organic source and mode of $N$ application on economic parameters}

There were significant response from planting stages, organic sources and mode of $\mathrm{N}$ application treatments on economic parameters such as net return and benefit cost ratio (Table 2). Significantly more net return and benefit cost ratio were obtained when transplanted at two leaved stage than three to four leaved stage. Application of FYM $10 \mathrm{t} \mathrm{ha}^{-1}$ was 


\begin{tabular}{|c|c|c|c|c|}
\hline Treatments & $\begin{array}{c}\text { Grain } \\
\text { yield } \\
\left(\mathrm{kg} \mathrm{ha}^{-1}\right)\end{array}$ & $\begin{array}{c}\text { Straw } \\
\text { yield } \\
\left(\mathrm{kg} \mathrm{ha}^{-1}\right)\end{array}$ & $\begin{array}{l}\text { Net } \\
\text { return } \\
(₹)\end{array}$ & $\begin{array}{c}\text { Benefit: } \\
\text { cost }\end{array}$ \\
\hline \multicolumn{5}{|l|}{ Planting stage } \\
\hline $\mathrm{G}_{1}: 2$ leaved stage & 5280 & 7752 & 31567 & 0.86 \\
\hline $\mathrm{G}_{2}: 3-4$ leaved stage & 4702 & 6919 & 24142 & 0.66 \\
\hline $\operatorname{SEm} \pm$ & 73 & 128 & 48 & 0.001 \\
\hline $\operatorname{LSD}_{0.05}$ & 210 & 367 & 137 & 0.004 \\
\hline \multicolumn{5}{|l|}{ Organic source } \\
\hline $\mathrm{M}_{1}: \mathrm{FYM}\left(10 \mathrm{t} \mathrm{ha}^{-1}\right)$ & 5539 & 8119 & 33556 & 0.89 \\
\hline $\mathrm{M}_{2}: \mathrm{FYM}\left(5 \mathrm{tha}^{-1}\right)$ & 4533 & 6679 & 23263 & 0.66 \\
\hline $\begin{array}{l}M_{3}: \text { FYM } \\
\left(5 \mathrm{tha}^{-1}+\mathrm{Azo}\right)\end{array}$ & 4902 & 7210 & 26746 & 0.73 \\
\hline $\mathrm{SEm} \pm$ & 90 & 157 & 59 & 0.002 \\
\hline $\mathrm{LSD}_{0.05}$ & 257 & 450 & 168 & 0.005 \\
\hline \multicolumn{5}{|l|}{ Mode of $\mathrm{N}$ application } \\
\hline $\mathrm{N}_{1}:$ Blanket split & 4739 & 6977 & 24612 & 0.67 \\
\hline $\mathrm{N}_{2}: \operatorname{LCC} 3$ & 4992 & 7335 & 27911 & 0.76 \\
\hline $\mathrm{N}_{3}: \operatorname{LCC} 4$ & 5242 & 7695 & 31041 & 0.85 \\
\hline $\mathrm{SEm} \pm$ & 90 & 157 & 59 & 0.002 \\
\hline LSD 0.05 & 257 & 450 & 168 & 0.005 \\
\hline Control mean & 2260 & 3367 & 2833 & 0.11 \\
\hline Mean of the rest & 4991 & 7336 & 27855 & 0.76 \\
\hline $\mathrm{SEd} \pm$ & 164 & 287 & 107 & 0.003 \\
\hline $\operatorname{LSD}_{0.05}$ & 332 & 581 & 217 & 0.006 \\
\hline $\mathrm{G}_{1}$ Control & 2651 & 3943 & 7877 & 0.30 \\
\hline $\mathrm{G}_{2}$ Control & 1868 & 2790 & -221 & -0.08 \\
\hline $\mathrm{SEm} \pm$ & 220 & 385 & 144 & 0.004 \\
\hline $\operatorname{LSD}_{0.05}$ & 630 & 1102 & 412 & 0.012 \\
\hline CV (\%) & 8 & 10 & 1 & 1.02 \\
\hline
\end{tabular}

${ }^{*} 1$ US \$ = ₹ 56.0850 on 31.05 .2012

economically beneficial as net return and benefit cost ratio were significantly higher than FYM $5 \mathrm{t} \mathrm{ha}^{-1}+$ Azospirillum application and FYM $5 \mathrm{t} \mathrm{ha}^{-1}+$ Azospirillum was significantly profitable over FYM $5 \mathrm{tha}^{-1}$. Economic parameters were found significantly higher under $\mathrm{N}$ application at LCC 4 than LCC 3 and LCC 3 was observed significantly higher than blanket split treatment in respect of the economic parameters. Rest of the treatments other than controls registered significantly higher net return and benefit cost ratio than control treatments and between controls, two leaved stage transplanted control treatment was found significantly more profit oriented than three to four leaved stage transplanted control treatment.
3.5. Effect of planting stage, organic source and mode of $N$ application on nutrient uptake

Planting stages, organic sources and mode of $\mathrm{N}$ managements significantly influenced nutrient uptakes (Table 3). N, P and K uptakes were significantly higher under two leaved stage than three to four leaved stage. Among organic sources, under FYM $10 \mathrm{tha}^{-1}, \mathrm{~N}, \mathrm{P}$ and $\mathrm{K}$ uptakes were significantly higher than half of its doses with or without Azospirillum and their uptakes were significantly higher under FYM $5 \mathrm{t} \mathrm{ha}^{-1}+$ Azospirillum than FYM $5 \mathrm{tha}^{-1}$ alone. $\mathrm{N}$ and $\mathrm{K}$ uptakes were significantly higher and P uptake was numerically higher under LCC 4 over LCC 3 treatment and $\mathrm{N}$ and $\mathrm{P}$ uptakes were significantly higher and $\mathrm{K}$ uptake was numerically higher under LCC 3 than blanket split treatment. Nutrient uptakes were significantly less under control treatments than rest of the treatments and under two

Table 3: Effect of planting stage, organic source and mode of $\mathrm{N}$ application on nutrient uptake in boro rice under SRI

\begin{tabular}{|c|c|c|c|}
\hline Treatments & $\begin{array}{c}\text { Total N } \\
\text { uptake } \\
\left(\mathrm{kg} \mathrm{ha}^{-1}\right)\end{array}$ & $\begin{array}{c}\text { Total P } \\
\text { uptake } \\
\left(\mathrm{kg} \mathrm{ha}^{-1}\right)\end{array}$ & $\begin{array}{c}\text { Total K } \\
\text { uptake } \\
\left(\mathrm{kg} \mathrm{ha}^{-1}\right)\end{array}$ \\
\hline \multicolumn{4}{|l|}{ Planting stage } \\
\hline $\mathrm{G}_{1}: 2$ leaved stage & 154.1 & 46.9 & 85.7 \\
\hline $\mathrm{G}_{2}: 3-4$ leaved stage & 140.0 & 38.0 & 77.2 \\
\hline $\mathrm{SEm} \pm$ & 1.4 & 0.9 & 1.9 \\
\hline $\mathrm{LSD}_{0.05}$ & 4.1 & 2.5 & 5.4 \\
\hline \multicolumn{4}{|l|}{ Organic source } \\
\hline $\mathrm{M}_{1}: \mathrm{FYM}\left(10 \mathrm{t} \mathrm{ha}^{-1}\right)$ & 164.0 & 47.9 & 97.4 \\
\hline $\mathrm{M}_{2}:$ FYM $\left(5 \mathrm{t} \mathrm{ha}^{-1}\right)$ & 131.8 & 37.0 & 68.3 \\
\hline $\mathrm{M}_{3}:$ FYM $\left(5 \mathrm{t} \mathrm{ha}^{-1}+\mathrm{Azo}\right)$ & 145.3 & 42.3 & 78.6 \\
\hline $\mathrm{SEm} \pm$ & 1.8 & 1.1 & 2.3 \\
\hline $\mathrm{LSD}_{0.05}$ & 5.0 & 3.0 & 6.6 \\
\hline \multicolumn{4}{|l|}{ Mode of $\mathrm{N}$ application } \\
\hline $\mathrm{N}_{1}:$ Blanket split & 137.3 & 38.0 & 75.5 \\
\hline $\mathrm{N}_{2}: \operatorname{LCC} 3$ & 147.0 & 43.1 & 79.8 \\
\hline $\mathrm{N}_{3}: \mathrm{LCC} 4$ & 156.8 & 46.1 & 89.0 \\
\hline $\mathrm{SEm} \pm$ & 1.8 & 1.1 & 2.3 \\
\hline $\mathrm{LSD}_{0.05}$ & 5.0 & 3.0 & 6.6 \\
\hline Control mean & 51.1 & 13.9 & 36.0 \\
\hline Mean of the rest & 147.0 & 42.4 & 81.4 \\
\hline $\operatorname{SEd} \pm$ & 3.2 & 1.9 & 4.2 \\
\hline $\mathrm{LSD}_{0.05}$ & 6.5 & 3.9 & 8.5 \\
\hline $\mathrm{G}_{1}$ Control & 61.3 & 20.0 & 46.7 \\
\hline $\mathrm{G}_{2}$ Control & 40.9 & 9.7 & 25.2 \\
\hline $\mathrm{SEm} \pm$ & 4.3 & 2.6 & 5.6 \\
\hline $\mathrm{LSD}_{0.05}$ & 12.3 & 7.4 & NS \\
\hline CV (\%) & 5.4 & 11.3 & 12.7 \\
\hline
\end{tabular}


leaved stage control treatment, nutrient uptake was significantly higher over three to four leaved stage.

Growth attributing as well as yield attributing characters were higher when rice was transplanted at two leaved stage and as a consequence, higher grain and straw yields were achieved under two leaved stage transplanted condition. Nutrient uptakes were also higher under two leaved stage transplanted treatment. Manjunatha et al. (2009) reported that transplanting of rice seedling earlier ( 9 days old or 12 days old) produced significantly higher grain yields than transplanting of aged seedlings ( 15 days old, 18 days old and 21 days old). Singh et al. (2013) also registered that transplanting of ten days old rice seedlings were significantly better than those of other age of 12 and 14 days old seedlings in respect of yield attributes, grain yield, economics, nutrient uptake and soil health.

FYM 10 t ha $^{-1}$ produced highest grain and straw yields followed by FYM $5 \mathrm{tha}^{-1}+$ Azospirillum and further followed by FYM $5 \mathrm{t}$ ha ${ }^{-1}$ and the yields were well supported by the growth attributes and yield attributes, which were influenced by the organic sources treatments in the same pattern as in case of yields. Treatment effects were also in the same pattern on nutrient uptakes. Among $\mathrm{N}$ management treatments, $\mathrm{N}$ application at LCC 4 provided highest growth attributes and yield attributes followed by LCC 3 and further followed by blanket split treatment and as a resultant effect, yields were also responded in the same pattern in respect of the treatments. Yields were also supported by the nutrient uptakes as they were observed in the similar trend. Singh et al. (2009b) reported that the nitrogen use efficiency and apparent recovery were significantly higher with LCC based $\mathrm{N}$ management than the recommended $\mathrm{N}$ management in temperate condition of Kashmir. Joshi et al. (2013) reviewed that $\mathrm{N}$ application should be based on a critical LCC value of 4 for high-yielding varieties of rice. LCC based $\mathrm{N}$ management practice produced maximum tillers/hill, plant height, straw, and paddy yield as compared to $\mathrm{N}$ application according to recommended dose and farmer's practice at Mingora, Swat in Pakistan as reported by Ahmad et al. (2016).

\section{Conclusion}

Transplanting at two leaved stage was favourable for higher yield under SRI in boro rice. Application of FYM @ $10 \mathrm{t}$ ha ${ }^{-1}$ produced higher grain and straw yields than half of its dose with or without Azospirillum. There was response from Azospirillum application with FYM $5 \mathrm{t} \mathrm{ha}^{-1}$. In boro rice, LCC based $\mathrm{N}$ application provided better response to obtain higher grain as well as straw yields than blanket split and among the LCC values, LCC 4 was better than LCC 3 .

\section{References}

Ahmad, N., Zada, A., Junaid, M., Ali, A., 2016. Bridging the yield gap in rice production by using leaf color chart for nitrogen management. Journal of Botany, available at http://dx.doi. org/10.1155/2016/2728391.

Barison, J., Uphoff, N., 2011. Rice yield and its relation to root growth and nutrient-use efficiency under SRI and conventional cultivation: an evaluation in Madagascar. Paddy Water and Environment. doi: 10.1007/s10333-0100229-z.

Chapagain, T., Yamaji, E., 2010. The effects of irrigation method, age of seedling and spacing on crop performance, productivity and water-wise rice production in Japan. Paddy Water and Environment 8(1), 81-90.

CRRI, 2013. Vision 2050. ICAR-Central Rice Research Institute, Cuttack, Odisha, 8. Available at http://www.crri.nic.in/ ebook_crrivision2050_final_16Jan13.pdf.

G.O.I., 2014. Agricultural Statistics at a Glance 2014. Government of India, Ministry of Agriculture, Department of Agriculture and Cooperation, Directorate of Economics and Statistics, New Delhi, 63.

Joshi, E., Kumar, D., Lal, B., Nepalia, V., Gautam, P., Vyas, A.K., 2013. Management of direct seeded rice for enhanced resource-use efficiency. Plant Knowledge Journal 2(3), $119-134$.

Mahapatra I.C., Rao K.S., Panda B.B., Shivay, Y.S., 2012. Agronomic research on rice (Oryza sativa) in India. Indian Journal of Agronomy 57(3s), 9-31.

Manjunatha, B.N., Policepatil, A.S., Harsha, K.N., Ahmed, T., 2009. Effect of age of seedlings under different system of rice intensification (SRI). Journal of Crop and Weed 5(1), 277-280.

Mishra, A., Salokhe, V.M., 2008. Seedling characteristics and early growth of transplanted rice under different water regimes. Experimental Agriculture 44, 1-19.

Singh, B., Singh, V., Singh, Y., Gupta, R.K., 2009a. Need based field specific nitrogen management in rice for high fertilizer use efficiency. Indian Farming 58(12), 11-14.

Singh, D.K., Singh, J.K., Singh, L., 2009b. Real time nitrogen management for higher $\mathrm{N}$ use efficiency in transplanted rice (Oryza sativa) under temperate kashmir conditions. Indian Journal of Agricultural Sciences 79(10), 772-775.

Singh, K., Singh, S.R., Singh, J. K., Rathore, R. S., Singh, S. P., Roy, R., 2013. Effect of age of seedling and spacing on yield, economics, soil health and digestibility of rice (Oryza sativa) genotypes under system of rice intensification. Indian Journal of Agricultural Sciences 83(5), 479-483.

Zhao, L., Wu, L., Li, Y.S., Lu, X.H., Zhu, D.F., Uphoff, N., 2009. Influence of the system of rice intensification on rice yield and nitrogen and water use efficiency with different application rates. Experimental Agriculture 45, 275-286.

Zhao, L., Wu, L., Li, Y.S., Sarkar, A., Zhu, D.F., Uphoff, N., 2010. Comparisons of yield, water use efficiency, and soil microbial biomass as affected by the system of rice intensification. Communication in Soil Science and Plant Analysis 41, 1-12. 